\title{
RELATIONSHIP BETWEEN CAPPED LENDING RATE AND NON-PERFORMING LOANS OF LISTED COMMERCIAL BANKS IN KENYA
}

\author{
Wanjiku G. Thuita \\ Riara University \\ thuitagladys@gmail.com
}

\begin{abstract}
The study sought to establish the relationship between capped lending rate and non-performing loans among the listed commercial banks in Kenya. The secondary data for the study was collected from 2013-2017. The research tested the null hypotheses that capped lending rate has no significant relationship on non-performing loans of the listed commercial banks in Kenya. The study adopted descriptive research design to test the null hypotheses. The study found out that the capped lending rate has positively influenced the non-performing loans of the listed commercial banks in Kenya. The study therefore concludes that capped lending rate has helped in improving non-performing loans of the listed commercial banks in Kenya. The study recommends that listed commercial banks in Kenya should make efforts to improve capped lending rate because it has been found to have a positive effect on non-performing loans of the listed commercial banks in Kenya. The study will be of help to the banking sector, Central Bank of Kenya and other policy makers aligned to the financial institutions.
\end{abstract}

\section{Keywords}

non-performing loans; capped lending rate, banking sector; correlations; Central Bank of Kenya

\section{JEL Classification}

E13

\section{Introduction}

According to economist the rate of interest (lending rate) is determined through demand for money (deposits) and money supply (loans and advances). With increase in lending rate, the borrowers are expected to pay high interest amount which sometimes end becomes a burden. Before the capping of the lending rate, borrowers from the commercial banks in Kenya paid back the borrowed amount at an average rate of $17 \%$ from 2013 until third quarter of 2016 when the banks reverted to exorbitant rates and the government through parliament passed a law to cap the lending rate at $4 \%$ above the Central Bank of Kenya base rate.

According to Boudriga, Boulila and Jellouli (2009), a loan qualifies to be in state of non-performing when the principal and the interest payments are past 90 days or more. Non-performing loans is an expense to the banks translating to reduced profit margins. Balgova, Nies \& Plekhanov (2017), argues that the non performing loans can be a result of the customer inability or unwillingness to service their loans. The nonperforming becomes a burden to both the lenders and the borrowers and for the borrowers the colleratel is trapped by the lender until the loan is fully recovered or dispossed off to recover the outstanding loan. According to Chege (2014), high lending rate increases the non- perfoming loans and inability to pay the principal and the interest. Non-performing loans affects the gross domestic product and investment 
growth of an economy. Countries that manage to address the high non-performing loans achieve long run economic growth.

The lending rate and the non-performing loans can either be negatively or a positively correlated. Other factors such as the size of the bank and risk profile tend to influence the relationship between the lending rate and the NPLs (Chege, 2014). It is important for individual banks to control the NPLs to achieve desirable performance and the financial environment with minimum provisions for bad and doubtful debts to cushion the banks on the risk that results to reduced profit margin and eventually the collapse of the banking sector and the economy at large (Waweru and Kalani, 2009). The financial crisis in Asia and Sub-Saharan Africa was a result of the NPLs (Karim, et al., 2010).

To manage default risk, the government of Kenya introduced Credit Reference Bureau (CRB). The financial institutions are expected to share credit information as a ration to ensure that once the customer borrows from one financial institution and fail to pay the principal plus the interest, then listing is done and it become difficult to access finances elsewhere. Despite the existence of CRB the banks still contiunes to record high nonperforming loans (NPLs)with statistics showing that in the year 2016, 316,455 individuals out of a group of 600,000 had been listed in the CRB increasing the credit risk and the lending power (Central Bank of Kenya, 2017).

Despite the drastic measure to cap the lending rate one year down, the banks continue to incur massive losses from the non-performing loans. The banking sector plays a vital role towards the economic growth of a country with a positive contribution to Gross Domestic Product in 2016 at $5.8 \%$ compared to 5.7\% in 2015 (Kenya National Bureau of Statistics, 2017). The sector has faced a number of challenges and the latest being in the year 2016 when Chase Bank of Kenya was placed under receivership for reporting of insider loans and failure to meet statutory banking ratios (Central bank of Kenya, 2016).

\section{Statement of the Problem}

Empirical evidence shows that countries that previously caped the lending rate uncapped within a span of less than one year after capping citing issues of nonperformance of the economy thus creating empirical gap (Miller 2013; Makinde, 2016). Past studies show that there exist a positive relationship between the lending rate and non-performing loans (Ng'etich, 2011; Otieno, 2013; Munialo, 2014). The above studies have been conducted before the capping of the lending rate thus the need to add knowledge on the association between the capped lending rate and the non-performing loans. This study sought to address both the methodological and knowledge gap through conducting a rigorous study on the relationship between the capped lending rate and the non-performing loans among the listed commercial banks in Kenya.

\section{Specific Objective}

The specific objective of this study is to establish the relationship between the capped lending rate and the non-performing loans of the listed commercial banks in Kenya.

\section{Research Hypothesis}

Ho1: Capping the lending rate has no significant relationship on the non-performing loans of the listed commercial banks in Kenya. 


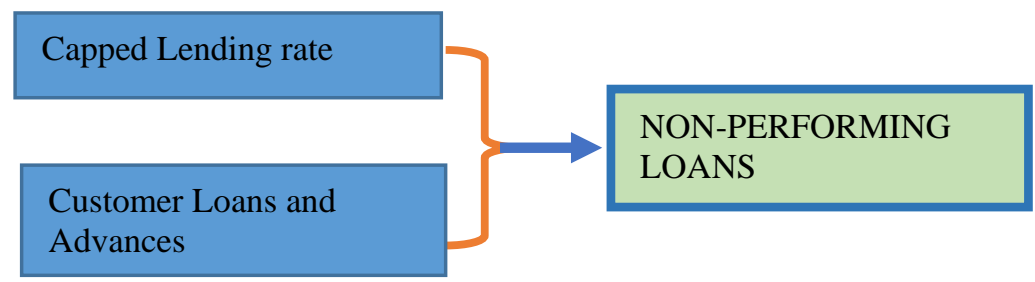

Figure 1: Conceptual framework

\section{Methodology}

A research design is a plan, structure and strategy of investigation so conceived to obtain answers to the questions or problems. The study used descriptive research design and secondary data was sourced data from the banks financial statements. The independent variables in this study was capped lending rate and customers loans and advances while the dependent variable is the non-performing loans of the listed commercial banks in Kenya. To analyze the data, the secondary data was correlated using Pearson correlation using Statistical Package for the Social Sciences. Regression analysis was also used so as to establish the relationship between capped lending rate and the non-performing loans. The study sampled 5 out of 11 commercial banks listed in the Nairobi Securities Exchange. The five banks which were sampled include Kenya Commercial Banks, Barclays Bank of Kenya, NIC, Equity Bank and Co-operative Bank of Kenya.

\section{Correlations for Capped Lending Rate and Non-Performing Loans}

In order to determine the relationship between capped lending rate and the nonperforming loans, the study conducted a correlation analysis between capped lending rate and the non-performing loans and results offered in Table 4.1.

Table 4.1 Correlations for Capped Lending Rate and Non-Performing Loans

\begin{tabular}{|c|c|c|c|}
\hline & 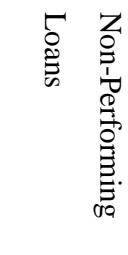 & 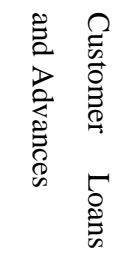 & 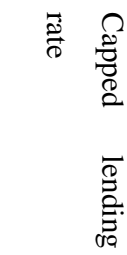 \\
\hline Non-Performing Loans & 1 & & \\
\hline Customer Loans and Advances & $.690^{*}$ & 1 & \\
\hline Capped Lending Rate & $.752 * *$ & $.340^{*}$ & 1 \\
\hline
\end{tabular}

$* * \mathrm{P}<.01$ level (2-tailed), $* \mathrm{p}<.05$ level (2-tailed).

The study correlation analysis results showed that association between capped lending rate and the non-performing loans was statistically significant and positive $(r=0.752$, $\mathrm{p}<0.01)$. The association between capped lending rate and the customer loans and advances was also positive and statistically significant $(\mathrm{r}=0.340, \mathrm{p}<0.05)$, customer 
loans and advances and non-performing loans were correlated positively $(\mathrm{r}=.690, \mathrm{p}<$ $.05)$.

Regression Analysis between Capped Lending Rate and Non-Performing Loans The object was to establish the relationship between the capped lending rate and the non-performing loans of the listed commercial banks in Kenya. In an effort to establish the relationship between the capped lending rate and the non-performing loans of listed commercial banks in Kenya, the study had set the following research hypothesis;

$\mathbf{H}_{01}$ : Capped lending rate has no significant relationship on the non-performing loans of the listed Commercial banks in Kenya.

In testing the hypothesis, the study used regression coefficient (beta $\beta$ ). The mean score of non-performing loans of the listed commercial banks in Kenya measures were regressed against the mean score of measures of capped lending rate and results presented in the table below.

Table 4.2 (a) Regression Results for Capped Lending Rate and Non-Performing Loans

Model Summary

\begin{tabular}{ccccc}
\hline Model & $\mathrm{R}$ & R Square & Adjusted R Square & Std. Error of the Estimate \\
1 & $.752^{\mathrm{a}}$ & .565 & .420 & 34.67774 \\
\hline
\end{tabular}

a. Predictors: (Constant), Capped Lending Rate

The study regression finding shows that 56.5 percent of non-performing loans of the listed commercial banks in Kenya can be explained by capped lending rate (R squared $=0.56 .5$ ) table 4.2 (a). The study findings found out that there was an influence of capped lending rate on non-performing loans of the listed commercial banks in Kenya. This concurs with Nasieku (2014) who found out that the price of the loan does affect the NPLs at $43.8 \%$ and the remedial for NPLs is for the banks to conduct effective risk assessment.

Table 4.2 (b) Regression Results for Capped Lending Rate and Non-Performing Loans

ANOVA $^{\mathrm{a}}$

\begin{tabular}{|c|c|c|c|c|c|c|}
\hline & Model & Sum of Squares & df & $\begin{array}{c}\text { Mean } \\
\text { Square }\end{array}$ & $\mathbf{F}$ & Sig. \\
\hline \multirow{3}{*}{1} & Regression & 4683.183 & 1 & 4683.183 & 3.894 & $.043^{b}$ \\
\hline & Residual & 3607.637 & 4 & 1202.546 & & \\
\hline & Total & 8290.819 & 5 & & & \\
\hline
\end{tabular}

a. Dependent Variable: Capped Lending Rate

b. Predictors: (Constant), Non-Performing Loans

The relationship between the capped lending rate and the non-performing loans of the listed commercial banks in Kenya was positive and significant in that its $\mathrm{R}$ was .752 (table 4.2a). From the regression analysis, the study found out that there is a relationship between the capped lending rate and the non-performing loans on the listed commercial banks in Kenya although it was statistically significant ( $\mathrm{p}$-value $=.043$ ). 
The study therefore rejected the null hypothesis since the p-value was less than .05 (.043).

Table 4.2 (c) Regression Results for Capped Lending Rate and Non-Performing Loans

Coefficients

\begin{tabular}{|c|c|c|c|c|c|c|}
\hline \multicolumn{2}{|c|}{ Model } & \multicolumn{2}{|c|}{$\begin{array}{c}\text { Unstandardized } \\
\text { Coefficients }\end{array}$} & \multirow{2}{*}{$\begin{array}{c}\begin{array}{c}\text { Standardized } \\
\text { Coefficients }\end{array} \\
\text { Beta }\end{array}$} & \multirow[t]{2}{*}{$\mathrm{t}$} & \multirow[t]{2}{*}{ Sig. } \\
\hline & & B & Std. & & & \\
\hline & & & Error & & & \\
\hline \multirow{2}{*}{1} & (Constant) & 22.226 & 143.190 & & 2.949 & .060 \\
\hline & Capped Lending Rate & .798 & 8.765 & .752 & 1.973 & .043 \\
\hline
\end{tabular}

a. Dependent Variable: Non-performing loans

The regression results shows that relationship between the capped lending rate and the non-performing loans of the listed commercial banks in Kenya was positive and significant at individual level $(\beta=.752, p$-value .043$)$ but it was statistically significant in that the p-value was than 0.05 ). The resultant model from the relationship between the capped lending rate and the non-performing loans of the listed commercial banks in Kenya and which may be used to estimate non-performing loans given the level of capped lending rate is as follows;

$\mathrm{NPL}=22.226+.752 \mathrm{CLR}+\varepsilon$

Where:

NPL is non-performing loans

22.226 is the $y$ - intercept constant

.752 is the beta $(\beta=.752)$ or the slope coefficient.

CLR is capped lending rate

$\varepsilon$ is the error term

\section{Discussions}

The regression results show that 56.5 percent of non-performing loans of the listed commercial banks in Kenya (R squared $=0.565$ ) was accounted for by capped lending rate. The study therefore found out that there was a relationship between the capped lending rate and the non-performing loans of listed commercial banks in Kenya were positive. This shows that capped lending rate employed by listed commercial banks in Kenya has helped improve on non-performing loans. The study results concur with the results of a study done by Chege (2014) which showed that most of the banks NPLs went up with only listed commercial banks in Kenya dropping with less than 2.0 billion from 2016 to 2017. The banks liabilities (customer deposits) are the determinants of the loans the bank is expected to give out to its customers.

\section{Conclusions and Recommendations}

The study found out that 56.5 percent of non-performing loans of the listed commercial banks in Kenya can be explained by the capped lending rate. Therefore, the study found out that there was a relationship between the capped lending rate and the nonperforming loans of the listed commercial banks in Kenya. Based on the study findings the study concludes that capped lending rate has helped to improve the non-performing loans of the listed commercial banks in Kenya. 
The study recommends that listed commercial banks in Kenya should make efforts to improve on capped lending rate because it has been found by this study to have a positive effect on non-performing loans of the listed commercial banks in Kenya

\section{References}

Balgova, M., Nies, M., \& Plekhanov, A. (2017).The economic impact of reducing nonperforming loans, (193).

Boudriga, A., Boulila, N., \& Jellouli, S. (2009). Does bank supervision impact Nonperforming loans: cross-country determinants using aggregate data?. University of Tunis: ESSEC, DEFI.

Central Bank of Kenya (2015; 2016; 2017). Published Articles.

Chege, M.(2014). Effect of interest rates on non-performing loans in Commercial Banks In Kenya.

http://www.znfu.org.zm/article/bank-zambia-removes-caps-interest-rates

Institute of Certified Public Accountants of Kenya (2016). Banking Sector Reforms Vital for Growth. Nairobi.

Karim, A., Chan, G. \& Hassan, S. (2010). Bank Efficiency and Non-Performing Loans: Evidence from Malaysia and Singapore.

Kenya Bureau of Statistics (2017). Economic Survey Launch, Nairobi.

Kenya Economic Outlook (2016). The Story Behind the Numbers,Nairobi.

Mbua, S. (2017). Effects of Interest Rate Capping by the Central Bank of Kenya on the Banks Listed on the Nairobi Securities Exchange. United States International University.

Makinde, O. (2016). Effect of Interest Rate on Commercial Bank Deposits in Nigeria.

Miller, H. (2013). Interest rate caps and their impact on financial inclusion.

Munialo, J. (2014). The relationship between lending rate and non performing loans in commercial banks in kenya, University of Nairobi.

Mwakolobo, B. (2013). The impact of financial sector in the economic growth in Nigeria.

Nasieku, N. (2014). Factor affecting non-performing loans: A case of Commercial Bank of Africa, Kenya. United States International University-Africa.

Ng'etich, J. (2011). The effects of interest rates spread on the level of nonperforming assets. A case of commercial banks in Kenya. International journal of business and public management.1, (1), 58-65

Otieno, M. (2013). Non-performing loans of commercial banks in Kenya. University of Nairobi.

Republic of Kenya (2007). Kenya Vision 2030- Popular Version.pdf

Waweru, N. \& Kalani, M. (2009). Commercial Banking Crises in Kenya: Causes and Remedies, African Journal of Accounting. Vol. 4, No. 4, pp. 12-32.

World Bank Group (2014). Interest Rate Caps around the World Still Popular, but a Blunt Instrument. 